\begin{tabular}{|l|l|l||}
\hline \multicolumn{2}{|c|}{ PublisherInfo } \\
\hline \hline PublisherName & $:$ & BioMed Central \\
\hline \hline PublisherLocation & $:$ & London \\
\hline \hline PublisherImprintName & $:$ & BioMed Central \\
\hline \hline
\end{tabular}

\title{
Malaria in profile
}

\begin{tabular}{|l|l|l||}
\hline \multicolumn{2}{|c|}{ ArticleInfo } \\
\hline \hline ArticleID & $:$ & 4822 \\
\hline \hline ArticleDOI & $:$ & $10.1186 /$ gb-spotlight-20030801-01 \\
\hline \hline ArticleCitationID & $:$ & spotlight-20030801-01 \\
\hline \hline ArticleSequenceNumber & $:$ & 174 \\
\hline \hline ArticleCategory & $:$ & Research news \\
\hline ArticleFirstPage & $:$ & 1 \\
\hline \hline ArticleLastPage & $:$ & 2 \\
\hline \hline & & RegistrationDate : 2003-8-1 \\
\hline ArticleHistory & $:$ & OnlineDate \\
\hline \hline ArticleCopyright & $:$ & BioMed Central Ltd2003-8-1 \\
\hline \hline ArticleGrants & $:$ & \\
\hline \hline ArticleContext & $:$ & 130594411 \\
\hline \hline
\end{tabular}




\section{Cathy Holding}

Email: cholding@hgmp.mrc.ac.uk

Malaria is perhaps the most important parasitic disease worldwide, is caused the protozoan Plasmodium - P. falciparum causes the severest form of the human disease - and is responsible for half a billion cases of infection and up to 2.7 million deaths each year, most frequently in children. In the July 31 Sciencexpress, Karine Le Roch and colleagues at The Scripps Research Institute use microarray technology and statistical analysis and report the gene expression profiling of nine different stages of the parasite's life cycle, including human and mosquito stages. They observe that similar expression profiles of genes in particular tissues reflect similarity of function, providing direction for the analysis of the function of predicted hypothetical gene sequences (Sciencexpress 2003, DOI:10.1126/ science.1087025,).

Le Roch et al. generated a microarray of 367,226 single-stranded $25 \mathrm{mer}$ probes from predicted coding and noncoding sequences that represented, on average, one probe every 150 base pairs of DNA, and they obtained a quantitative estimate of transcript abundance in RNA from each developmental stage. They observed $88 \%$ of predicted genes were expressed in at least one stage of the lifecycle and showed the shift in transcription from protein synthesis through to cell surface structures. Forty-three percent of genes were cell-cycle regulated, while 51\% were constitutively expressed, including housekeeping and hypothetical genes with no human equivalent orthologue, which could represent targets for drug development. Grouping genes on the basis of time and level of expression resulted in 15 clusters in which hypothetical predicted genes could have function assigned to them, and analysis of chromosomal organization indicated that chromosomal location and coexpression of genes were linked.

"Altogether these data provide a detailed description of the transcriptional events that occur throughout the lifecycle of the malaria parasite. In addition, we have shown that the identification of genes with similar expression patterns can facilitate the determination of possible function of hypothetical proteins and as a consequence, have provided clues about the potential cellular roles of over a thousand hypothetical proteins," the authors conclude.

\section{References}

1. Severe falciparum malaria in children: current understanding of pathophysiology and supportive treatment

2. Sciencexpress, [http://www.scienceexpress.org]

3. The Scripps Research Institute, [http://www.scripps.edu/]

This PDF file was created after publication. 